\title{
The Know Nothings in Iowa: Opportunity and Frustration in Antebellum Politics
}

\section{RONALD MATTHIAS}

THE STORY OF KNOW NOTHINGISM is in part the story of one of those remarkable outbursts of nativistic sentiment that have from time to time punctuated American history. But it is more-and less-than that. Thrusting itself into the confused political arena of the mid-1850s, the Know Nothing movement quickly demonstrated that nativism was for many little more than a facade, behind which lurked a multitude of interests and schemes-some praiseworthy, some reprehensible, some inconsistent, some even contradictory.

Over the nation as a whole, Know Nothingism had a tendency to mean different things to different people-and even to the same people at different times. Ostensibly opposed to alien influences in American life, its development in the North was very different from its development in the South. Even within regions, the Know Nothing appeal varied considerably from state to state and from county to county. When to all of this is added the Know Nothing commitment to secrecy (at least in the early days), we begin to understand why no serious historian has been courageous enough-or perhaps foolhardy enough-to undertake a comprehensive survey of the Know Nothing movement on a national scale. And until the recent publication of Tyler Anbinder's superb Nativism and Slavery: The Northern Know Nothings and the Pol-

THE ANNALS OF IOWA 53 (Winter 1994). (CThe State Historical Society of lowa, 1994. 
itics of the 1850s, even solid regional studies have been conspicuous by their absence from bibliographies on the $1850 \mathrm{~s}^{1}$

For all of its strengths, Anbinder's study pays relatively little attention to the Know Nothings in Iowa. The Iowa story is both fascinating and significant, in part because of what it says about the role of the Know Nothings in the collapse of the second American party system and the creation of the Republican party. ${ }^{2}$ Equally important, the experience of the Hawkeye state helps to clarify the societal context within which the strange career of the Know Nothings unfolded. If we are to understand that career, we need to unravel the seeming mystery of how and why so many Americans were attracted so suddenly (and often so briefly) to a mid-century political crusade against Roman Catholics and the foreignborn.

IN IOWA, as elsewhere, the Know Nothings moved from obscurity to prominence almost overnight. The organization first appeared in the Hawkeye state during the summer of 1854 , too late to play a significant role in the stunning victory of James Grimes and the "Opposition" over the Democratic party in the August election of that year. By October, a Know Nothing state council had been organized; and, during the next few months, a temporary stillness in the Kansas storm permitted Iowans to turn their attention from the extension of slavery to other issues and concerns. During the winter of 1854-55, Know Nothing organizers established local councils throughout the state. During the same months, a number of influential newspapers, including the Muscatine Journal and the Davenport Gazette, joined the Know Nothing cause. In early 1855 the Know Nothings won a series of key municipal elections, enabling them to control four of the six most important cities in the state: Davenport, Iowa City, Keokuk, and Muscatine. And in April 1855, by engaging in a grand

1. Tyler Anbinder, Nativism and Slavery: The Northern Know Nothings and the Politics of the 1850s (New York, 1992).

2. Robert R. Dykstra, Bright Radical Star: Black Freedom and White Supremacy on the Hawkeye Frontier (Cambridge, 1993), 129-36, provides a useful summary and analysis of the political career of the Know Nothings in Iowa. See also Dykstra's article in this issue. 
fusion with nearly every non-Democratic faction in Iowa, they were able to elect all three of their candidates for state office. In less than a year the Know Nothings had become a power in Iowa politics. One can scarcely blame them for expecting additional successes in the months and years to come. ${ }^{3}$

The party's expectations were quickly placed in jeopardy, however, by the consequences of popular sovereignty in Kansas. As news of lawlessness and disorder on the Kansas plains made its way into the columns of the Iowa press during the spring of 1855 , the slavery issue once again became the focal point of public discussion. Fears of papal conquest and foreign influence, if not forgotten, suddenly seemed far less important than they had a few months earlier. Compounding the problem for Iowa Know Nothings was the adoption of an essentially proslavery platform by the national council of the party in June 1855.

As antislavery sentiment spread rapidly in Iowa, a new competitor confronted the Know Nothings. "Republicans" called conventions in a number of counties during the summer of 1855. In some cases Know Nothings figured prominently in the proceedings. When returns from the August county elections of that year demonstrated an evaporation of Know Nothing strength over much of the state, the Know Nothing press, apparently sensing the direction the political winds were blowing, swung suddenly to the support of a campaign to organize a Republican party in Iowa. In the months that followed, the same sentiment infiltrated the ranks of the Know Nothing organization. Those who had an investment in that organization and who still looked to it for political success were consequently reduced to two alternatives: forestall the Republican movement, or fuse with it.

The first alternative was, from the standpoint of most Know Nothings, clearly preferable. But was it feasible? Conceivably it was. If the Know Nothing party of Iowa were to adopt as its own an essentially Republican platform, it might

3. This and the following paragraphs summarize or, in some cases, are taken directly from my Ph.D. dissertation, "The Know Nothing Movement in Iowa" (University of Chicago, 1965). 
retain, or secure, the support of most of those in the state who opposed the extension of slavery. Consequently, in November 1855 the Know Nothing state council drew up a platform concentrating almost exclusively on the slavery issue. But it failed to stall the Republican drive. The Know Nothings quickly discovered that the Republicans already held most of the trump cards in the antislavery game. Republican recruiting continued to decimate Know Nothing ranks. The Republican position on slavery was clearly popular not only in Iowa, but throughout the North. And the Republicans could hope to draw support from a quarter the Know Nothings could never touch-the "foreign vote."

Under the circumstances, the Know Nothings' best alternative was fusion with the Republicans for the 1856 campaign. Fusion was accomplished, but on Republican terms, and under Republican auspices, when the first Iowa Republican state convention on February 22, 1856, nominated for state office four candidates, three of whom possessed solid Know Nothing connections. Once again, faithful Know Nothings faced two unpalatable alternatives: either support the Republican nominees, or place a second slate of Know Nothing nominees in the field-a choice, in short, between political oblivion and political impotency.

Most antislavery Know Nothings chose the first alternative. But there were more than a few nativists in Iowa who did not share the antislavery predilections of the majority. Managing to secure control of a lightly attended American party (that is, Know Nothing) state convention in March 1856, they repeated the Republican nominations for state office. By nominating a separate slate of presidential electors pledged to support American candidate Millard Fillmore, however, they signaled their determination to keep an American party in the field.

Following that convention, no further effort was made to maintain the state organization. Surviving antislavery Know Nothings gradually drifted into the ranks of the Republican party. A number of so-called National Know Nothings, who opposed the Republican position on slavery in the territories and who saw in the American organization a means of avoiding sectional conflict, continued to maintain organizations on a 
county or township basis-particularly in extreme southern Iowa. But they enjoyed no political success. In the August 1856 elections American party candidates throughout the state were shut out at the polls-in most cases by humiliating margins. Fillmore's fate in November was equally unhappy. Receiving only 10 percent of the lowa vote, he carried not a single county in the state. What little support he had came not so much because of his connection with nativism, but rather because of his appeal as a national, conservative candidate.

A brief effort to revive the American organization in 1857 was marked only by ignominious failure; never again did any candidate for political office in Iowa run as a Know Nothing. On the other hand, charges of Know Nothing ancestry and nativism did continue to spice Iowa politics until the eve of the Civil War.

KNOW NOTHING SUCCESSES in Iowa, limited and transitory though they were, deserve explanation. How could a party that based its appeal to the electorate on proscriptive principles attract such an extensive following-even temporarily? Any answer to this question ought to involve not only a listing of the attractions of Know Nothingism, but also some attempt to assess their comparative importance.

Whatever else the Know Nothing movement in Iowa may have represented, it was not an indigenous explosion of latent hostilities toward Roman Catholicism. This is not, of course, the same as saying that Iowans were free from antiCatholic prejudice. They, like the overwhelming majority of their compatriots, grew up in a society that fostered a tradition of fear and hostility toward the Church of Rome. Although many American institutions contributed to the maintenance of this tradition, it received constant nourishment from a large portion of the Protestant clergy in Iowa, particularly representatives of the American Home Missionary Society, whose quarterly reports to the society regularly reflected an intense fear and hatred of Catholicism. ${ }^{4}$ But a

4. American Home Missionary Society Correspondence, State Historical Society of lowa, Des Moines; Matthias, "The Know Nothing Movement in Iowa," 45-49. 
strong tradition of open hostility to Catholicism never took root in Iowa before the appearance of the Know Nothings in 1854. Many Iowans may have distrusted Roman Catholics; and they may have preferred, other things being equal, not to live in the shadow of a Catholic church. Certainly they were no more immune than other Americans to the influences of a pervasive American tradition of anti-Catholicism. But these same Iowans were concerned about what must have seemed to them more important matters.

Iowa was a youthful state-full of promise, but as yet quite undeveloped. What the state needed more than anything else was people-people with (as they put it) "strong arms and resolute hearts." Every newcomer to Iowa was both a potential and an actual source of wealth for the state. But "strong arms and resolute hearts" were not the exclusive possession of Protestants. Roman Catholics possessed them, too. Consequently, when Bishop Mathias Loras of Iowa made strenuous efforts to attract to the Hawkeye state Catholic settlers from Europe and the eastern seaboard states, few Iowans objected. Loras himself testified to the willingness of pioneer lowans to put pocketbook before prejudice when he reported that Protestants in the infant town of Bellevue were eager to have a Catholic church there in order to attract settlers and thereby increase the value of their landed investments. And in 1844 Loras described Dubuque as "the most quiet place in America. Protestants are not bigoted here, they respect us, and will never threaten to assassinate the poor Bishop." ${ }^{5}$

Another reason anti-Catholicism failed to develop strong roots in Iowa was the Roman Catholic Church's obvious inability to achieve a significant measure of power and influence in the state. If Rome had marked out Iowa for conquest, as the early American Home Missionary Society missionaries believed, that conquest signally failed to materialize. Despite

5. M. M. Hoffmann, "The Roman Catholic Church in Iowa," Palimpsest 34 (1953), 352-53; Loras, quoted in John F. Kempker, History of the Catholic Church in Iowa (Iowa City, 1887), 37; and in M. M. Hoffmann, The Church Founders of the Northwest: Loras and Cretin and Other Captains of Christ (Milwaukee, 1937), 181. 
Bishop Loras's efforts to attract Catholic settlers, there were by 1854 only fifteen thousand Roman Catholics in the state, less than 5 per cent of the total population. ${ }^{6}$ As a result, the Catholic Church was hardly in a position to invite trouble by appearing arrogant. At the same time, other Iowans could afford to be tolerant of so small a minority. Despite constant underlying tension and a few minor outbursts, conflict between Catholics and non-Catholics was muted. Iowa was not marching in the ranks of the "Protestant Crusade" before 1854.

In July of that year the Dubuque Observer did launch a vitriolic editorial campaign of abuse against Roman Catholicism. In succeeding months, other members of the Iowa press joined that campaign. ${ }^{7}$ But, for the most part, open expressions of anti-Catholicism developed after rather than before the appearance of the Know Nothing movement in the state. Furthermore, most of the complaints leveled against Catholics merely repeated charges that had been making the rounds in the East for some time. Few applied directly or uniquely to Iowa. The campaign against Catholicism in late 1854, then, was more effect than cause-a justification for the existence of Know Nothingism, not its source.

Know Nothingism was not able to sustain itself during its brief career in Iowa by feeding upon an established tradition of virulent anti-Catholicism. Would its prospects for nourishment have been any better if it had concentrated on the alleged threat to American institutions arising from the existence of a considerable immigrant population within the state? Was there deeper antipathy toward the foreign-born than toward the Roman Catholic, and if so, could the Know Nothings have capitalized upon it?

The earliest white settlers of the territory and state of Iowa were largely native-born Americans, many of southern stock. From the very beginning of settlement they were joined by a lesser number of people who had begun their journey to Iowa in some foreign land, most often Germany or

6. Kempker, History of the Catholic Church in Iowa, 40-41.

7. Matthias, "The Know Nothing Movement in Iowa," 4-16. 
Ireland. By 1856 roughly one Iowan in seven listed another country as place of nativity. ${ }^{8}$

The existence of this substantial foreign-born population in Iowa created an opportunity for the development of concrete ethnic tension. Occasional notes of nativistic hostility were struck, but usually in direct response to allegedly undesirable behavior on the part of the foreign-born. Both German and Irish voters, during the 1840 s and early 1850 s, were staunch supporters of the Democratic party. The Whigs, invariably on the losing side in elections, consequently complained from time to time about the "foreign vote." But during the course of election campaigns, the Whigs, seeking to woo this vote, were as full of praise of naturalized voters as were the Democrats. ${ }^{9}$

Cultural differences could be potential sources of conflict. For example, the disdainful attitude of some Germansparticularly Forty-eighters-toward religion and community moral standards was one source of irritation. Theodor Gülich, editor of the German-language Davenport Demokrat, created a considerable stir in 1853 by suggesting that Americans get rid of "the obsolete idea that ours ought to be a christian country." Iowans also complained from time to time about the failure of the foreign-born to show proper respect for that venerable American institution-the sober Sabbath. Germans, in particular, were fond of Sunday ballroom activities, which most Iowans regarded as a desecration of the Lord's Day. Beyond this, both the Germans and the Irish persistently opposed having their drinking habits regulated by law-at the very time when the crusade for a Maine Law was reaching a crescendo in Iowa. Obviously, it was not difficult for "native" Iowans to find fault with the foreign-born, particularly, because of their prominence, the Germans and Irish. And there was almost constant tension between the American and immigrant communities in parts of early Iowa. ${ }^{10}$

8. John A. T. Hull, comp., Iowa Historical and Comparative Census, 18361880 (Des Moines, 1883), 168-69.

9. Matthias, "The Know Nothing Movement in Iowa," 64.

10. Davenport Gazette, 25 August 1853; Matthias, "The Know Nothing Movement in Iowa," 67-76. 
But the tension, insofar as it did exist, seldom approached the breaking point. On the contrary, most Iowans found the foreign-born to be, on balance, far more desirable than undesirable. In the Iowa press, praise outweighed complaint by an overwhelming margin. Some of the enthusiasm was undoubtedly little more than an expression of frontier boosterism. On the other hand, many editorials reflected a faith in America's mission to serve as a haven for the oppressed and less fortunate of every land. Others suggested that the foreign-born, having demonstrated their love for liberty by emigrating to this country, would infuse new strength into American democracy. ${ }^{11}$

The case for the foreign-born, however, was most frequently based on economic considerations. The Davenport Gazette spoke for many lowans when it said in 1854, "Though immigration is large, we would not impede it. We apprehend no bad consequences from its extent. The difficulty is not that we have too many laborers, but too few. How could our canals and railroads have been built without the strong Irish and German immigrants? How would our new States and Territories have been settled, and their wilderness made to blossom like the rose, had there been less encouragement for aliens to flock thither and become citizens?"12 In other words, immigration was wealth; immigrants were indispensable to the economy of a frontier state. This fact of life came to be generally recognized during territorial and early statehood years in Iowa, and, as a result, helped prevent serious ethnic conflict.

Thus, few Iowans were ready to embark on a nativistic crusade before the Know Nothing party made its appearance in the state. Once organized, of course, the party could draw on a reservoir of ill will that had been generated in past months and years. But most of the complaints of Iowa Know Nothings against the foreign-born, after the organization of the party, applied more to the situation in eastern states than in Iowa. The same general charges were repeated time after time until they began to read like a political catechism. Rarely

11. Matthias, "The Know Nothing Movement in lowa," 65-66.

12. Davenport Gazette, 15 June 1854. 
was there any indication that, with respect to the foreignborn, the local situation demanded the existence of organized nativism. Given the general conditions of the mid-1850s, Know Nothingism might well have thrust itself upon the Iowa scene with nearly the same success had there been not a single immigrant-or, for that matter, a single Roman Catholic-in the state.

One possibly serious objection to this conclusion deserves consideration. The year in which the Know Nothing party was established in Iowa was also a year of intense temperance agitation. Most of the foreign-born could fairly be charged with unalterable opposition to having their drinking habits regulated by legislative enactment. At the same time, those Iowans who enlisted in the ranks of Know Nothingism were almost unanimously staunch supporters of such legislation. ${ }^{13}$ Is it possible, then, that the Iowa Know Nothing party was primarily an anti-liquor response to the alleged fondness of the Germans for "lager bier" and the Irish for whiskey?

A high degree of correlation between Know Nothingism and temperance sentiment might be expected if the former had become the political vehicle for the latter. But it did not. Prominent temperance advocates, such as James Thorington and Hiram Price, supported the Know Nothing movement, but a host of others seem never to have done so. In fact, Rev. Henry Clay Dean, an untiring Methodist spokesman for the prohibitory cause, was the most brilliant and articulate of all Iowa critics of Know Nothingism. ${ }^{14}$

There is also the matter of timing. The Know Nothing party developed in Iowa after the August 1854 election-an election in which the people of the state had chosen in James Grimes a governor friendly to the prohibitory cause, and a legislature that would probably enact its demands. A Know Nothing party almost certainly would have supported the cause, but it is hard to understand how any politically

13. An analysis of biographical data on the leaders of the Know Nothing movement in Iowa reveals virtually nothing-except solid support for legislated temperance-that would clearly distinguish them from their political opponents.

14. Matthias, "The Know Nothing Movement in Iowa," 18-20. 
minded Iowan at the time could have felt it necessary to create a new political party for the purpose of remedying the evils of intemperance. The Hawkeye state was well on its way toward legislated temperance-with or without a Know Nothing presence.

Neither the enactment of a prohibitory law by the legislature in late 1854 nor the ratification of that law by the people in April 1855 made the Know Nothing party superfluous. Know Nothing strength did begin to wane during the second quarter of 1855 , possibly due in part to the departure of temperance men who had got what they wanted. But if some of these men abandoned the nativist cause for that reason (and there is little evidence that they did), most of them did not. The affinity between temperance enthusiasts and Know Nothingism lay much deeper than a mere conscious desire to strike at the enemies of legislated morality.

Hostility toward Catholics and the foreign-born was not fundamental in generating the Know Nothing movement in Iowa. Subsequent Know Nothing rhetoric did, of course, express such hostility, but for most Iowa Know Nothings that rhetoric was more a matter of rationalization than of rationale. Know Nothingism was a kind of political magpie's nest created out of an unusual assortment of interests and concerns. Some of the interests were noticeably remote from genuine fear of alien influence, but all stood to benefit from participation in a nativistic crusade.

INITIALLY, the Know Nothing movement in Iowa was not the consequence of an outburst of mass sentiment; it was instead the calculated creation of politicians, many of whom seem to have been far more concerned with political gain than they were with the ideology of nativism. The Iowa political situation in 1854 almost demanded the formation of a new political organization. The once potent Whig party had fallen upon hard times, and was precariously close to breathing its last, despite the victory of James W. Grimes in the gubernatorial contest of 1854. The Iowa Democracy was in considerably better health than were the Whigs, but it too had more than its share of political ailments. Rent by factionalism, divided over temperance, almost torn asunder by the 
impact of the Kansas-Nebraska bill, the party could no longer command the allegiance of a majority of Iowans. No great amount of political sagacity was required to perceive that the confused party situation had created a splendid opportunity for the formation of a new political organization to oppose the Democracy, which had dominated state politics since territorial days. The materials were readily available: orphaned Whigs, alienated Democrats, free-soilers, and a host of political dissidents of every kind. All that was needed was political leadership capable of welding those diverse elements into an opposition party. Such leadership was quickly forthcoming, and the result was the formation of the Know Nothing party in Iowa-fundamentally a response of politicians to political opportunity of the first order. ${ }^{15}$

Granted that there was plenty of room for a new political organization in Iowa in 1854, why should eager politicians have seen their brightest chances for success in the creation of a nativistic organization? Grimes, after all, had been elected governor in August after a campaign in which he had concentrated on opposition to the Kansas-Nebraska bill-and in which nativism had been at most a distinctly minor issue. Would it not have made far more sense under the circumstances to have worked for the creation of a party opposed to the extension of slavery? Since the men involved in launching the Know Nothing organization in lowa were, on the whole, antislavery men, this alternative was undoubtedly considered-and rejected. The decision probably rested upon several considerations.

First, there was good reason in late 1854 to question both the relevance and the potential durability of a party devoted primarily to the slavery issue. Earlier that year opposition to the Kansas-Nebraska bill had been good politics. But once the bill became law and it became apparent that there was lit-

15. State Know Nothing leaders included William Penn Clarke of lowa City, James Thorington of Davenport, William H. Tuthill of Tipton, and William Loughridge of Mahaska County. Newspaper editors supportive of the cause included James B. Howell (Keokuk Gate City), William M. Stone (Knoxville Journal), Alfred Sanders (Davenport Gazette), John Mahin (Muscatine Journal), Nathaniel M. Hubbard (Linn County Register [Marion]), and Wells Spicer (Tipton Advertiser). 
tle prospect of repealing it, much of the excitement it had generated began to evaporate. ${ }^{16}$ For the moment, there was no way of foreseeing the violence in Kansas that a few months later would again make the slavery-extension issue the focal point of Iowa politics. In late 1854 and early 1855 , therefore, it made good sense to doubt that a "Republican" party could win major elections in the Hawkeye state.

For politicians whose chief concern was success, the Know Nothing party had considerably more to recommend it. It was potentially national rather than sectional, and seemed to be concerned about the permanence of the Union. By subordinating the slavery issue, it might draw support from nearly all segments of the political spectrum. Furthermore, unlike the Republican party, the fledgling Know Nothing organization had already successfully tested its political wings. Its rapid development in the East had been almost unbelievable, and it emerged from the various state and local elections of 1854 with an amazing record of success. Under the circumstances, Iowa politicians can scarcely be blamed for concluding that Know Nothingism might well be the wave of the future. If nativistic appeals to the electorate could achieve such results in eastern states, why not in Iowa as well?

The mushroom growth of the Know Nothing order in Iowa during the early months of its existence suggests that these expectations were not altogether unfounded. Party organizers expected mass support-and they got it. But not all Iowans who flocked to this proscriptive order did so for the same reasons. For some-though probably a relative few-it was an opportunity to express genuine ethnic and religious tensions that may have been smoldering for some time. Others were drawn by curiosity, or by the attractions of secrecy and ritual. For many disgusted Whigs and Democrats, it must have been a convenient means of escaping old party ties.

From the very beginning, but particularly during 1855 and 1856, Know Nothingism attracted those Iowans who

16. "Know Nothingism is the Only remaining formidable issue...," Henry Clay Dean to George W. Jones, Iowa City, 22 January 1855, Henry Clay Dean Collection, State Historical Society of Iowa, Des Moines. 
feared that growing sectional conflict might tear the nation apart. As an organization, it claimed to be broadly national and conservative-well equipped to still the waves of sectional agitation and thereby save the Union. In the process, rights and interests of certain segments of the population would have to be sacrificed, but undoubtedly more than a few Iowans considered this a small price to pay for union.

That kind of thinking undoubtedly accounts for, in part at least, the strength and persistence of nativism in a number of counties just north of the Missouri state line. Those counties were settled chiefly by southerners, and therefore by people who were caught squarely in the middle of the increasing sectional conflict of the $1850 \mathrm{~s}$. Tied by memories and family connections to the South, some were avowedly proslavery. Most seem to have shared an intense dislike of both African-Americans and abolitionists. Nevertheless, they were now residents of a free state, and as a result many of them possessed a special sensitivity to the demands of the North as well as the South. Wholehearted commitment to one side or the other was often next to impossible. Consequently, many did their best to straddle-or avoid-the issues that seemed to drive a wedge between the sections. Politically, however, that was not easily done in the mid1850 s. Nothing could any longer be expected from the Whig party. The Democracy could fairly be charged with having reopened the wounds of sectional bitterness when it supported the Kansas-Nebraska bill in 1854. And when later the Republican party made itself available to Iowans, it gave every indication of wishing to fan the flames of sectional passion rather than to extinguish them. ${ }^{17}$

On the other hand, the Know Nothing organization, with its emphasis on the Union and patriotism, was an ideal political vehicle for Iowans who wished to subordinate the sources of sectional conflict. And for ex-southerners living in the lower tiers of counties, it was attractive in still another sense. Catholics and foreign-born residents were conspicuous by their absence in much of that area. ${ }^{18} \mathrm{~A}$ campaign directed

17. See the Bloomfield True Flag, 1855-1856.

18. 1856 Iowa Census, 15, 19, 94, 98, 254, 261, 304, 308, 319, 321. On the 
against them would consequently involve a minimum of political risk.

Taken together, these various attractions help to account for the success of the Know Nothing organization in Iowa. They also help to explain why that success was so shortlived. Nevertheless, they do not constitute an entirely adequate survey of the resources from which the Know Nothing movement drew its strength.

First, these factors do not adequately account for the magnitude of support the party received. More particularly, all of them presuppose that the decision to support the Know Nothings was a deliberate, rational response to consciously identifiable problems or opportunities, many of which were only remotely related to genuine concern over alien threats to American institutions. Presumably, then, most Iowa Know Nothings were deliberately willing to make scapegoats of Catholics and the foreign-born in order to achieve social and political objectives of various kinds.

Undoubtedly deliberate scapegoating was often involved. But it is nearly impossible to read through the literature of the Know Nothing movement in Iowa without becoming impressed by the emotional intensity and sincerity of many who professed their faith in proscription. Certainly a good many Iowans during the years 1854-1856 were genuinely fearful of alien influence in American life. What is considerably less certain is why they should have been so fearful. Concrete religious and ethnic tensions were relatively weak in Iowa. Furthermore, Know Nothing rhetoric in Iowa seldom concerned itself with the local scene, but rather repeated the same vague, general, and often unsubstantiated charges against immigrants and Catholics that were printed ad nauseam in Know Nothing publications in the East. That rhetoric may have kept in touch with reality, but certainly there was no firm grasp involved. The best it could manage was sour complaint about alleged shortcomings in American society. Never did it provide any kind of realistic program for the elimination of those shortcomings or for the solution of those

Catholic Church in southern Iowa, see N. Howe Parker, Iowa As It Is in 1855 (Chicago, 1855), 257-58. 
problems that apparently so agitated the Know Nothing mind.

Yet somehow that rhetoric, despite its inherent irrationality and an obvious air of fantasy, appealed to more than a few Iowans in the mid-1850s, perhaps because nativism was for many a not altogether self-conscious response to the apparent disruption of American society. Those were years of unrest and confusion, of anxiety and disorder. Disturbing economic, social, and political changes occurred in such rapid-fire order that many citizens must have found themselves bewilderedand frustrated-as they sought to acquire a sense of meaning and direction in their lives. Seemingly the very foundations of the nation were shaking. Somehow something had gone wrong with the promise of American life. The causes of disruption and confusion were complex and not easily comprehensible. It is not surprising, therefore, that many Americans, unable or unwilling to discover the real sources of their frustration, sought out instead simple causes and simple solutions. Both were readily available, and both were persuasively articulated in Know Nothing propaganda.

The threatened disintegration of American society could be viewed as the result of an erosion of fundamental American values. Know Nothing publicist Thomas $R$. Whitney put it in these words:

Religion, patriotism, and morality have been the foundation-stones of our success as a nation, and our happiness and prosperity as a people. These foundation-stones were laid upon the rock of a stern Protestant faith, and their fruits have been all that our institutions promised-civil and religious liberty. So long as the foundation and sub-structure remained firm and unshaken, so long we retained the assurance of a permanent government, and the guarantee of continued freedom.

But the foundation is being removed, and the rock upon which it was laid is in danger of being undermined. Imported infidelity is supplanting the religion of our fathers. It rears its unabashed visage, and boldly demands the abolition of all laws for the observance of the Sabbath. Patriotism is giving way to fanaticism and party spirit. A sectional war of opinion is now raging, which demands the disruption of our nation- 
the North from the South. The moral element of our success is diluted by the influence of imported vices and irreligion-and Romanism already begins to assert her supremacy over the Protestant basis of the Republic.

While these corroding changes are going on, it is impossible to hope that another quarter of a century will find our Union of States in existence, or our boasted and cherished institutions still shedding their invigorating and cheering example upon the nations of the earth. ${ }^{19}$

The solution to the problem was equally simple-a reaffirmation of and rededication to those principles that constituted the distinctive bases of American culture. In a culturally pluralistic nation, however, this presented some problems; hence the need (consistently reflected in Know Nothing literature) to define what was American and what was un-American, and a corresponding insistence on the necessity for homogeneity in American culture.

THIS EXPLANATION of the attractions of Know Nothingism for many Iowans is admittedly impressionistic; yet it has much to recommend it. It renders Know Nothing rhetoric comprehensible; it provides an explanation for how a multitude of Iowans may have been seized by a wholly unwarranted and unreasonable fear of immigrants and Catholics. But it also helps account for the coincidence of nativism, temperance, and antislavery in the minds of so many Iowans in the mid-1850s. Each of those reform movements was an attempt to reaffirm American traditions and to homogenize American institutions. It seems likely, therefore, that temperance advocates, for instance, were drawn to Know Nothingism not so much because it was an opportunity to strike at the opponents of temperance. Rather, the same kind of personality that would be attracted to temperance might often, in the context of those times, be similarly attracted to Know Nothingism. Thus, a general feeling of frustration generated by bewildering societal change was the prime factor in rally-

19. Thomas R. Whitney, A Defence of the American Policy (New York, 1856), 325-26. 
ing masses of Iowans around the standard of Know Nothingism-once, of course, that standard had been raised by opportunistic politicians.

Whatever the nature of the Know Nothing appeal, its hold on the political allegiance of Iowans was in most cases strikingly brief. Created out of the wreckage of older parties, the Know Nothing movement was an impossible combination of frustration and opportunism. Reasonable concern over alien influences in American life was a perfectly legitimate response to the events of the early $1850 \mathrm{~s}$. But the creation of a secret political organization to deal with those influences betrayed an utter inability to relate means to ends. Never did the party leadership propose a nativistic platform or program that got much more specific than an insistence that "Americans should rule America." Possibly nothing more could be expected of an organization that attracted its adherents for such a variety of reasons. The inevitable result was a party with little potential for either constructive achievement or permanence.

Yet, in the final analysis, the failure of Know Nothingism in Iowa-as elsewhere-was more than a case of congenital malformation. Doubtless the party would not have survived for long under any circumstances, but the development in 1855 and 1856 of a groundswell of concern over the slavery question hastened its death. The formation of the Republican party in Iowa created a competitor that spoke far more appealingly to the concrete concerns of Iowans than did the Know Nothings. As fear of alien influence gave way to fear of the "slave power," Know Nothingism was swallowed up in Republicanism. 
Copyright of Annals of Iowa is the property of State of Iowa, by \& through the State Historical Society of Iowa and its content may not be copied or emailed to multiple sites or posted to a listserv without the copyright holder's express written permission. However, users may print, download, or email articles for individual use. 